\title{
Effect of feeding soybean, linseed oil and different forms of tocopherol on the redox and immune profiles of turkey hens
}

\author{
K. Ognik \& A. Czech \\ Department of Biochemistry and Toxicology, Department of Biology and Animal Production, University of Life Sciences, \\ Lublin, Poland, Akademicka 13, 20-950 Lublin
}

(Received 15 November 2012; Accepted 24 September 2014; First published online 29 October 2014)

Copyright resides with the authors in terms of the Creative Commons Attribution 2.5 South African Licence.
See: http://creativecommons.org/licenses/by/2.5/za
Condition of use: The user may copy, distribute, transmit and adapt the work, but must recognise the authors and the South African Journal of Animal
Science.

\begin{abstract}
The aim of the study was to analyse whether, and to what extent, the use of RRR-d-a-tocopherol in diets containing oil rich in linoleic or linolenic acid (soybean or linseed oil, respectively) would make it possible to halve the dosage of this antioxidant with respect to a-tocopherol without negatively affecting the redox and immune status of turkey hens. The experiment was carried out on 480 turkey hens, type BIG 6, which were divided into four groups. Birds in Group I (control) received soybean oil and synthetic dl-alphatocopherol acetate in their feed mixture. Group II received soybean oil and natural RRR-d-alpha-tocopherol. Birds in Group III received linseed oil and synthetic tocopherol, whereas those in Group IV had linseed oil and natural tocopherol. At the end of the ninth, eleventh and fifteenth weeks of life, blood was sampled from their brachial veins for analyses. Haematological, immunological and pro- and antioxidative parameters were measured. The application of linseed oil had a minor effect on the immune and antioxidative systems of the turkey hens. The study showed that the addition of the natural form of RRR-d-alpha-tocopherol with soybean and linseed oils stimulated the mechanisms of the antioxidative defence system more effectively than dlalpha-tocopherol acetate addition with these oils. It may be possible to use the natural form of tocopherol in diets rich in linoleic and linolenic acid (soybean/linseed oil) without detrimental effect on redox and immune status of turkey hens. However, the commonly used tocopherol acetate, despite the higher dosage, is cheaper. Thus, from an economic point of view, the use of linseed oil with the synthetic form of vitamin $E$ is worth recommending.
\end{abstract}

Keywords: Antioxidants, birds, blood, immunity, oil

\#Corresponding author: kasiaognik@poczta.fm

\section{Introduction}

In animal nutrition, fats are one of the major nutrients and serve a variety of functions. Tthe addition of fat itself is significant, and also its source, type of fatty acid constituting it and the degree of their oxidation. In turkey feeding, the main source of fat is usually soybean oil (Czech et al., 2012; Ognik et al., 2012). Fatty acids in soybean oil consist of $15 \%$ saturated fatty acids (SFA), $26 \%$ mono-unsaturated fatty acids (MUFA) and $59 \%$ polyunsaturated fatty acids (PUFA). Because it has a more favourable fatty acid composition, linseed oil should be more beneficial than soybean oil. It is rich in n-3 PUFAs (linoleic acid (LA) 14\%), and locked nucleic acid (LNA) 58\%), and contains 9\% SFA, 19\% MUFA and 72\% PUFA (Nuernberg et al., 2004; Hassan et al., 2011). As well as fatty acids, oils contain substances with antioxidative properties such as vitamin E and flavonoids, although their quantities are relatively low (Ramadan \& Moersel, 2006). Earlier studies (Prescha et al., 2008; Kania et al., 2004) reported that the concentrations of phenolic compounds in soybean and linseed oil are similar at between $12 \mu \mathrm{g} / \mathrm{g}$ and $20 \mu \mathrm{g} / \mathrm{g}$. Tocopherol (vitamin E) is a key nutrient, being simultaneously a functional component that protects fat against oxidation. The content of total tocopherol in soybean oil reaches $0.005 \%$, with a tocopherol profile of zero $\alpha$ and $\beta, 14 \mu \mathrm{g} / \mathrm{g}$ and $32 \mu \mathrm{g} \delta / \mathrm{g}$. In turn, the content of tocopherol in linseed oil reaches $0.083 \%$, with a profile of $20.7 \mu \mathrm{g} \alpha / \mathrm{g}, 0.4 \mu \mathrm{g} \beta / \mathrm{g}$, $803.4 \mu \mathrm{g} \mathrm{N} / \mathrm{g}$ and $9.2 \mu \mathrm{g} \delta / \mathrm{g}$ (Kania et al., 2004; Piescha, 2008).

The active components of linseed oil, owing to its high content of omega-3 fatty acids, might have immunomodulatory properties and influence various immune mechanisms, inter alia, to modulate the process of phagocytosis, the activity of NK cells and the production of cytokines (Calder et al., 2011; Ognik et al., 2012). 
Modulation of the antioxidative and immunological status of turkey hen bodies through optimizing the level and quality of feeding and selecting nutrients and functional components may help to improve the health status and production performance of birds. Therefore, the aim of the study was to analyse whether and to what degree the use of RRR-d-a-tocopherol in diets containing oil rich in linoleic or linolenic acid (soybean or linseed oil, respectively) would make it possible to halve the dosage of this antioxidant with respect to a-tocopherol without negatively affecting the redox and immune status of turkey hens.

\section{Materials and Methods}

The experiment was conducted with 480 turkey hens of the Big 6 line. The birds were 1 to 16 weeks old. They were assigned randomly to four experimental groups, 120 turkeys each, allocated to five replications per treatment with 24 birds each. The birds were kept in cages, $2.5 \times 2.5 \times 4 \mathrm{~m}$ in size, under recommended hygienic conditions for turkey fattening. To achieve the objectives of the investigation, the types of fat component and the level and chemical form of vitamin E precursor differed, and were added separately as feed supplements (E 307, according to the European Union Register of Feed Additives EEC 1831/2003). Group I (control) received soybean oil and synthetic dl-alpha-tocopherol acetate at dietary levels of $50 \mathrm{mg} / \mathrm{kg}$ ( 1 - 9 weeks of life) and $45 \mathrm{mg} / \mathrm{kg}$ (10 - 16 weeks of life), which is consistent with the vitamin E content recommended for turkey hens by the National Research Council (NRC) (1994). Group II received soybean oil as a fat component and natural RRR d-alpha-tocopherol (100\% activity) in a dose equivalent to the form of synthetic dl-alpha-tocopherol (i.e. $2.5 \mathrm{mg}$ of the synthetic form = $1 \mathrm{mg}$ of the natural form of tocopherol) in a dose of $25 \mathrm{mg} / \mathrm{kg}$ (1 - $9 \mathrm{wk}$ of life) and $22.5 \mathrm{mg} / \mathrm{kg}$ (10 - $16 \mathrm{wk}$ of life). Group III received linseed oil and synthetic dl-alpha-tocopherol acetate, whereas these from Group IV had linseed oil and natural RRR d-alpha-tocopherol (Table 1).

Table 1 Determined concentration of alpha tocopherol and fatty acids in dietary treatment groups

\begin{tabular}{|c|c|c|c|c|}
\hline \multirow{2}{*}{$\begin{array}{l}\text { Ingredients in experimental } \\
\text { treatments }\end{array}$} & \multicolumn{4}{|c|}{ Treatments } \\
\hline & $\begin{array}{c} \\
\text { control } \\
\end{array}$ & II & III & IV \\
\hline Soybean oil & + & + & - & - \\
\hline Linseed oil & - & - & + & + \\
\hline $\begin{array}{l}\text { Vitamin E (synthetic) } \\
\text { dl-alpha-tocopherol } \\
\text { Vitamin E (natural) } \\
\text { RRR-d-alpha-tocopherol }\end{array}$ & + & $\begin{array}{l}- \\
+\end{array}$ & + & $\begin{array}{l}- \\
+\end{array}$ \\
\hline $\begin{array}{l}\text { Dose vitamin } \mathrm{E} \text { in } \mathrm{mg} / \mathrm{kg} \\
(1-9 \text { weeks) } \\
\text { Content of alpha tocopherol } \\
\mathrm{mg} / \mathrm{kg} \text { in feed ( } 1 \text { - } 9 \text { weeks) }\end{array}$ & $\begin{array}{l}50 \\
53\end{array}$ & $\begin{array}{l}25 \\
30\end{array}$ & $\begin{array}{l}50 \\
52\end{array}$ & $\begin{array}{l}25 \\
31\end{array}$ \\
\hline $\begin{array}{l}\text { Dose vitamin } \mathrm{E} \text { in } \mathrm{mg} / \mathrm{kg} \\
(10-16 \text { week) } \\
\text { Content of alpha tocopherol } \\
\mathrm{mg} / \mathrm{kg} \text { in feed ( } 10-16 \\
\text { weeks) }\end{array}$ & 47 & $\begin{array}{l}22.5 \\
25.3\end{array}$ & 47.5 & 22.5 \\
\hline \multicolumn{5}{|l|}{ Fatty acids in feed mixture (\%) } \\
\hline SFA & 13.5 & 13.3 & 15.5 & 15.3 \\
\hline MUFA & 38.8 & 35.8 & 21.4 & 22.1 \\
\hline PUFA & 47.6 & 50.9 & 63.1 & 62.6 \\
\hline
\end{tabular}

The turkey hens were fed ad libitum and had free access to water. All the mixtures were based on wheat, maize meal, soybean meal, soybean/linseed oil, and isonitrogenous and isoenergetic balances were maintained (Table 2). The base mixture was introduced to the premix (vitamin and mineral supplement) without vitamin $\mathrm{E}$. The experiment was carried out with the approval of the local ethical committee (Second Local Ethical Committee for Animal Experiments, 2009). 
Feed samples collected at the end of the ninth and sixteenth weeks of the experiment were analysed for a-tocopherol content according to Manz \& Philipp (1981) using a Merck-Hitachi HPLC apparatus with LiChroCART 250-4 Superspher 100 RP-18, with $4 \mu \mathrm{m}$ column and FL detector, at Ex. $295 \mathrm{~nm}$ and Em. 350 $\mathrm{nm}$. The fatty acid profile of the feed samples was analysed with a gas chromatograph Varian CP 3800 with CP WAX capillary column of length $52 \mathrm{CB} 60 \mathrm{~mm}$ up to $210^{\circ} \mathrm{C}$, an FID detector and helium as carrier gas.

Table 2 Ingredient and nutrient content of experimental diets

\begin{tabular}{|c|c|c|c|c|c|}
\hline \multirow{2}{*}{ Ingredient } & \multicolumn{5}{|c|}{ Feeding period } \\
\hline & $\begin{array}{c}\text { Starter } \\
(1-2 \mathrm{wk} \\
\text { of age }) \\
\end{array}$ & $\begin{array}{c}\text { Grower I } \\
\text { (3 - } 5 \text { wk } \\
\text { of age) }\end{array}$ & $\begin{array}{c}\text { Grower II } \\
(6-9 \mathrm{wk} \\
\text { of age })\end{array}$ & $\begin{array}{c}\text { Grower III } \\
(10-12 \text { wk } \\
\text { of age })\end{array}$ & $\begin{array}{c}\text { Finisher I } \\
(14-16 \mathrm{wk} \\
\text { of age) }\end{array}$ \\
\hline Maize meal (g/kg) & 256 & 274 & 238 & 352 & 474 \\
\hline Wheat $(\mathrm{g} / \mathrm{kg})$ & 200 & 250 & 300 & 250 & 250 \\
\hline Wheat bran (g/kg) & 30 & - & - & - & - \\
\hline $\begin{array}{l}\text { Soybean meal }(\mathrm{g} / \mathrm{kg}) \\
46 \% \text { protein }\end{array}$ & 410 & 417 & 388 & 327 & 204 \\
\hline $\begin{array}{l}\text { Soybean meal }(\mathrm{g} / \mathrm{kg}) \\
45 \% \text { protein }\end{array}$ & 20 & - & - & - & - \\
\hline Fish meal 60\% (g/kg) & 35 & - & - & - & - \\
\hline Fodder chalk (g/kg) & 12 & 17 & 17 & 14 & 15 \\
\hline $\begin{array}{l}\text { Soybean oil or/ } \\
\text { linseed oil (g/kg) }\end{array}$ & 5 & 10 & 25 & 30 & 30 \\
\hline Cytromix Plus ${ }^{1}$ (g/kg) & 2 & 2 & 2 & 2 & 2 \\
\hline Farmix ${ }^{2}(g / k g)$ & 30 & 30 & 30 & 25 & 25 \\
\hline \multicolumn{6}{|c|}{ Calculated nutrient composition of $1 \mathrm{~kg}$ of mixture } \\
\hline Crude protein (g) & 271 & 255 & 245 & 220 & 175 \\
\hline Metabolisable energy (MJ) & 11.45 & 11.73 & 12.19 & 12.58 & 13.09 \\
\hline Crude fibre (g) & 28.6 & 27.7 & 27.2 & 27.1 & 27.0 \\
\hline Lysine (g) & 18.1 & 17.1 & 15.7 & 13.8 & 11.7 \\
\hline Methionine + Cysteine (g) & 9.8 & 9.0 & 8.8 & 7.9 & 7.0 \\
\hline Tryptophan (g) & 3.4 & 2.8 & 2.7 & 2.3 & 1.9 \\
\hline Arginine (g) & 17.7 & 15.7 & 15.0 & 13.2 & 9.8 \\
\hline Calcium (g) & 13.9 & 12.3 & 11.7 & 10.6 & 9.4 \\
\hline Phosphorus, available (g) & 7.7 & 6.7 & 5.9 & 5.7 & 4.7 \\
\hline Sodium (g) & 1.5 & 1.6 & 1.5 & 1.5 & 1.5 \\
\hline
\end{tabular}

\footnotetext{
${ }^{1}$ Cytromix Plus: citric acid, fumaric acid, phosphoric acid (62\%).

${ }^{2}$ Farmix: mineral and vitamin premix/kg diet: $3.33 \mu \mathrm{g}$ retinyl acetate (vitamin A); $149 \mu \mathrm{g}$ cholecalciferol (vitamin $\mathrm{D}_{3}$ ); $73.3 \mathrm{mg}$ menadione (vitamin $\mathrm{K}_{3}$ ); $100 \mathrm{mg}$ thiamine (vitamin $\mathrm{B}_{1}$ ); $292 \mathrm{mg}$ riboflavin (vitamin $\mathrm{B}_{2}$ ); $175 \mathrm{mg}$ vitamin $\mathrm{B}_{6} ; 0.9$ $\mathrm{mg}$ cobalamin (vitamin $\mathrm{B}_{12}$ ); $58.3 \mathrm{mg}$ folic acid; $10.5 \mathrm{mg}$ biotin; $2182 \mathrm{mg}$ niacin; $13333 \mathrm{mg}$ choline; $4200 \mathrm{mg}$ calcium pantothenicum; 4000 mg Mn; 2666 mg Zn; 1666 mg Fe; 833 mg Cu; 26 mg l; 10 mg Se; 6.7 mg Co; 13 g Ca; $15.5 \mathrm{~g} \mathrm{P}$.
}

Chromatographic separation was conducted with a Varian CP 3800 gas chromatograph. Over the experimental period, blood was sampled for analyses from the brachial veins of 10 birds from each treatment, in the sixth, eleventh and fifteenth weeks of life. Monotests developed by Cormay (PZ CORMAY S.A. Poland is a manufacturer of high-quality diagnostic reagents and the highest quality laboratory equipment) were used to determine samples of blood plasma spectrophotometrically for contents of the biochemical indices, uric acid (UA), urea (UREA), bilirubin (BIL) and creatinine (CREAT). Spectrophotometric assays were applied to analyse blood plasma samples for the activity of antioxidative enzymes, superoxide dismutase (SOD, EC 1.15.1.1) with the adrenaline method modified to the wavelength of $320 \mathrm{~nm}$ (to increase the selectivity of transient reaction products at this length of light (Bartosz, 2004)) and catalase 
(CAT, EC 1.11.1.6), according to Bartosz (2004). To calculate antioxidant status, the ferric-reducing ability of plasma (FRAP), blood plasma was assayed for vitamin C concentration and glutathione (GSSG + GSH) activity, according to Bartosz (2004). Blood was assayed for the concentration of a-tocopherol, according to Kaufmann (1958). In addition, the biological material was analysed for levels of lipid peroxidation products: peroxides $\left(\mathrm{H}_{2} \mathrm{O}_{2}\right)$ according to Gay \& Gębicki (2000), and malondialdehyde (MDA) as the end product of tissue lipid oxidation, according to Salih et al. (1987). Haematological tests included the determination of white blood cells (WBC) and percentage composition of white blood cells (leucogram) in stained blood smears, following Pappenheim's method (Bomski, 1989).

Immunological analyses involved determination of the phagocytic activity of leukocytes against strain 209P Staphylococcus aureus, expressed as the percentage of phagocytic cells (PC) and phagocytic index (PI), and the capability of heterophils to absorb and reduce nitroblue tetrazolium (NBT test) according to Park et al.'s method (1968). The blood plasma level of lysozyme activity (currently classified as a protective barrier of the body) was determined with the turbidimetric method (Pinkiewicz, 1971; Siwicki et al., 1993). The concentrations of selenium and manganese in blood plasma were determined in the Central Apparatus Laboratory, University of Life Sciences, Lublin, with the inflammable AAS technique on UNICAM 939.

All data were analysed as $2 \times 2$ factorial randomized block designs with tocopherol level and oil source and their interaction as the main effects, using a general analysis of variance (ANOVA) procedure of Statistica v. 6.1 software. Results are presented as treatment means and SEM. Significance of the difference between mean values was estimated by single-factor ANOVA, assuming the significance levels to be 0.05 and 0.01 (Asheber, 2012).

\section{Results}

The results on the parameters of the leucocytic system (Table 3) point to the great diversity among groups. A higher $(P<0.05)$ level of leucocytes was counted in the 6-week-old birds from Groups II - IV than in birds from Group I. In turn, at 11 weeks old, a significantly higher number of white blood cells (WBC) was observed in Group II turkey hens, which were supplemented with soybean oil and RRR-d-alpha-tocopherol, compared with Group I. However, at the end of the experimental period (week 15 of life) the number of WBC in Group II was lower $(P<0.05)$ than in the other groups. Nevertheless, taking into account the entire period of observation, the experimental factors were found not to affect changes in WBC count. The increase in WBC count determined in the first period of rearing in the turkey hens from Groups II - IV was accompanied by lymphopenia, which was also observed in the terminal period of rearing, particularly in the turkey hens administered linseed oil (Groups III and IV). Taking into consideration the entire rearing period, the highest number of basocytes was noted in the turkey hens fed the mixture with the addition of linseed oil and RRR$\mathrm{d}$-alpha-tocopherol. The increase in basocytes count, however, was owing to the application of linseed oil. In analysing the level of monocytes in the blood, the highest percentage of monocyte cells was recorded in the fifteenth week of life in the turkey hens from Group II (soybean oil + RRR-d-alpha-tocopherol). In contrast, the addition of the natural form of vitamin $\mathrm{E}$ to a feed mixture with linseed oil (Group IV) caused a significant decrease in the percentage of monocytes in the eleventh week of life, compared with Group I. Considering the mean content of monocytes in the entire rearing period, the above-described changes in the percentage of those cells undoubtedly affected the differences observed between the experimental groups. The coupled administration of linseed oil and RRR-d-alpha-tocopherol was observed to significantly reduce the percentage of monocytes in the leucocytic system.

Immunological analyses (Table 4) indicate a lack of significant effect on the stimulation of non-specific immunity (PI, NBT and lysozyme) of the hens. However, in the birds that received linseed oil with the synthetic form of tocopherol, a positive tendency was observed in the increasing values of the immunological parameters (percentage of PC and percentage of NBT-reducing cells), particularly at the end of the experimental period.

Values depicting tendencies of change in the redox process are presented in Tables 5, 6 and 7. There were no consistent changes in most of the parameters. Significant differences in the values of parameters, in particular rearing periods, seldom affected the final (mean) values of the parameters, and thus the differences between groups. In Groups II, III and IV, on average, the values reported for lipid peroxidation products $\mathrm{H}_{2} \mathrm{O}_{2}$ and MDA were lower by $47.5 \%$ and $34.6 \%$, respectively, compared with Group I (Table 7).

At the end of the rearing period (fifteenth week of life), increases $(P \leq 0.05)$ were observed in the activity of superoxide dismutase, that is, $14.5 \%$ in Group II, 26.8\% in Group III and 19\% in Group IV, compared with the control. The addition of linseed oil and the synthetic form of vitamin E for Group I caused a significant $(P \leq 0.05)$ enhancement in the activity of CAT. In turn, in the blood plasma of the hens receiving 
Table 3 Haematological parameters (white blood cells, leucogram) of blood of turkey hens

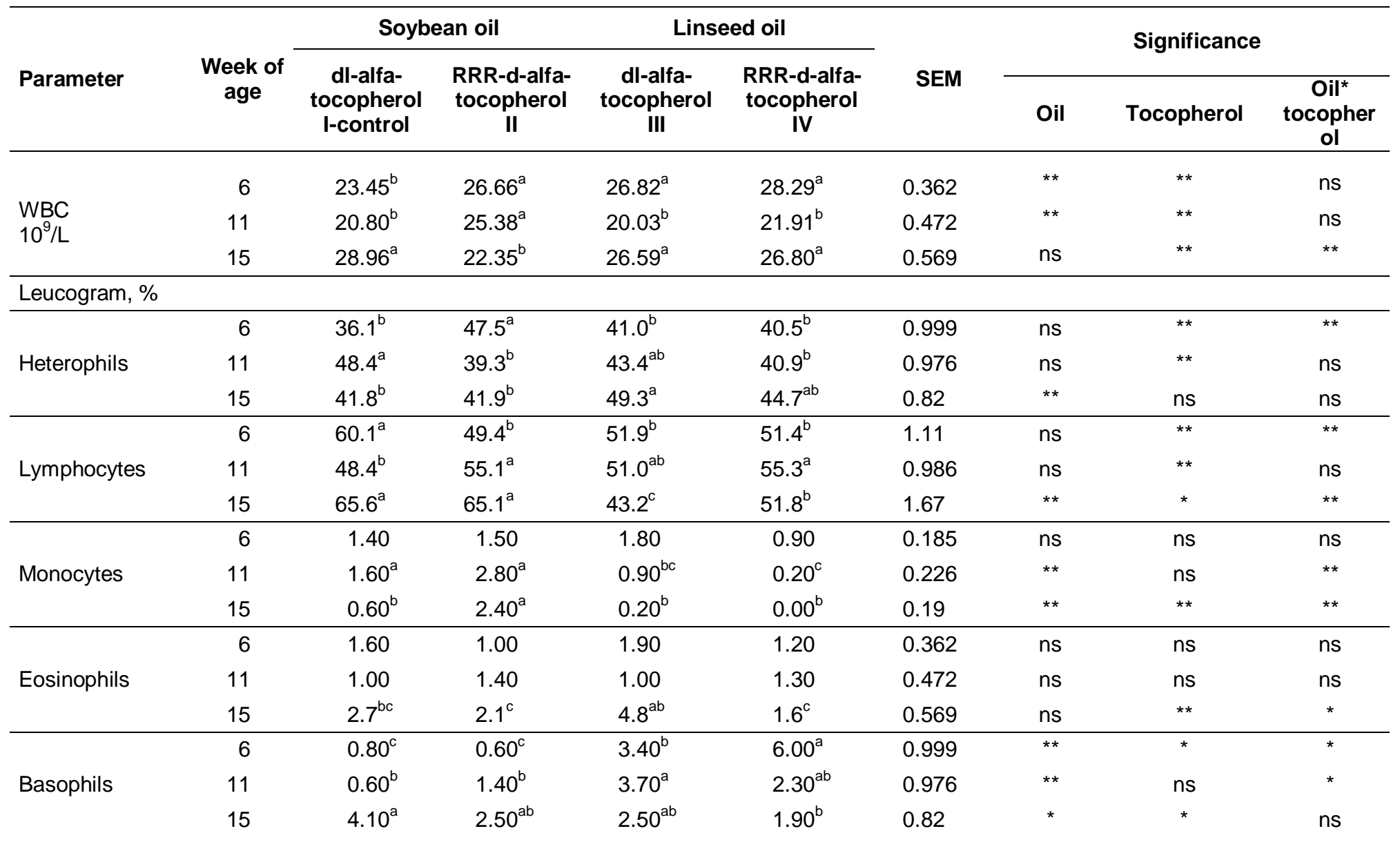

a, b, c. means within the row with different superscript differ significantly at $P \leq 0.05$ (compared with Group I).

ns: not significant $(P>0.05)$; * $(P \leq 0.05)$; ${ }^{\star \star}(P \leq 0.01)$; WBC: white blood cells. 
Table 4 Immunological parameters of blood of turkey hens

\begin{tabular}{|c|c|c|c|c|c|c|c|c|c|}
\hline \multirow{3}{*}{ Parameter } & \multirow{3}{*}{$\begin{array}{l}\text { Week of } \\
\text { age }\end{array}$} & \multicolumn{2}{|c|}{ Soybean oil } & \multicolumn{2}{|c|}{ Linseed oil } & \multirow{3}{*}{ SEM } & \multirow{2}{*}{\multicolumn{3}{|c|}{ Significance }} \\
\hline & & dl-alfa- & RRR-d-alfa- & dl-alfa- & RRR-d-alfa- & & & & \\
\hline & & $\begin{array}{l}\text { tocopherol } \\
\text { I-control }\end{array}$ & $\begin{array}{c}\text { tocopherol } \\
\text { II }\end{array}$ & $\begin{array}{c}\text { tocopherol } \\
\text { III }\end{array}$ & $\begin{array}{l}\text { tocopherol } \\
\text { IV }\end{array}$ & & Oil & Tocopherol & $\begin{array}{c}\text { Oil* } \\
\text { tocopherol }\end{array}$ \\
\hline \multirow{3}{*}{$\begin{array}{l}\text { Phagocytosis } \\
\text { cells } \\
\%\end{array}$} & 6 & 37.7 & 39.5 & 40.0 & 38.0 & 1.20 & ns & ns & ns \\
\hline & 11 & $40.7^{\mathrm{ab}}$ & $38.4^{\mathrm{ab}}$ & $45.5^{\mathrm{ab}}$ & $36.5^{b}$ & 1.23 & ns & * & ns \\
\hline & 15 & $39.4^{\mathrm{b}}$ & $42.3^{\mathrm{ab}}$ & $47.6^{\mathrm{a}}$ & $44.0^{\mathrm{ab}}$ & 1.13 & * & ns & ns \\
\hline \multirow{3}{*}{$\begin{array}{l}\text { Phagocytosis } \\
\text { index }\end{array}$} & 6 & 5.61 & 6.08 & 6.44 & 5.75 & 0.14 & ns & ns & * \\
\hline & 11 & 6.12 & 5.94 & 6.08 & 6.15 & 0.14 & ns & ns & ns \\
\hline & 15 & 6.06 & 6.31 & 6.56 & 6.01 & 0.11 & ns & ns & ns \\
\hline \multirow{3}{*}{$\begin{array}{l}\text { NBT: positive } \\
\text { heterophils } \\
\%\end{array}$} & 6 & 18.7 & 21.7 & 22.1 & 19.8 & 0.69 & ns & ns & ns \\
\hline & 11 & 17.4 & 16.6 & 19.0 & 17.2 & 0.54 & ns & ns & ns \\
\hline & 15 & $20.8^{\mathrm{ab}}$ & $19.1^{b}$ & $27.1^{\mathrm{a}}$ & $21.0^{\mathrm{ab}}$ & 1.08 & * & ns & ns \\
\hline \multirow{3}{*}{$\begin{array}{l}\text { Lysozyme } \\
\mu \mathrm{g} / \mathrm{mL}\end{array}$} & 6 & 1.65 & 2.02 & 1.87 & 1.72 & 0.09 & ns & ns & ns \\
\hline & 11 & 1.80 & 1.90 & 1.73 & 1.94 & 0.09 & ns & ns & ns \\
\hline & 15 & 1.85 & 1.93 & 1.80 & 2.03 & 0.09 & ns & ns & ns \\
\hline
\end{tabular}

a, b, c means within the row with no common superscript differ significantly at $P \leq 0.05$ (compared with Group I). ns: not significant $(P>0.05)$; * $(P \leq 0.05)$; ** $(P \leq 0.01)$.

NBT test: capability of heterophils to absorb and reduce nitroblue tetrazolium. 
Table 5 Biochemical parameters of blood plasma of turkey hens

\begin{tabular}{|c|c|c|c|c|c|c|c|c|c|}
\hline \multirow{3}{*}{ Parameter } & \multirow{3}{*}{$\begin{array}{l}\text { Week of } \\
\text { age }\end{array}$} & \multicolumn{2}{|c|}{ Soybean oil } & \multicolumn{2}{|c|}{ Linseed oil } & \multirow{3}{*}{ SEM } & \multirow{2}{*}{\multicolumn{3}{|c|}{ Significance }} \\
\hline & & dl-alfa- & RRR-d-alfa- & dl-alfa- & RRR-d-alfa- & & & & \\
\hline & & $\begin{array}{l}\text { tocopherol } \\
\text { l-control }\end{array}$ & $\begin{array}{l}\text { tocopherol } \\
\text { II }\end{array}$ & $\begin{array}{c}\text { tocopherol } \\
\text { III }\end{array}$ & $\begin{array}{l}\text { tocopherol } \\
\text { IV }\end{array}$ & & Oil & $\begin{array}{c}\text { Tocop } \\
\text { herol }\end{array}$ & $\begin{array}{c}\text { Oil* } \\
\text { tocopherol }\end{array}$ \\
\hline \multirow{3}{*}{$\begin{array}{l}\text { UA } \\
\mu \mathrm{mol} / \mathrm{L}\end{array}$} & 6 & $105.04^{\mathrm{ab}}$ & $95.64^{b}$ & $104.89^{\mathrm{ab}}$ & $107.92^{\mathrm{a}}$ & 1.62 & ns & ns & * \\
\hline & 11 & $127.08^{b}$ & $135.64^{\mathrm{ab}}$ & $144.50^{\mathrm{a}}$ & $134.11^{\mathrm{ab}}$ & 3.49 & ns & ns & ns \\
\hline & 15 & $158.57^{\mathrm{a}}$ & $102.01^{\mathrm{b}}$ & $157.93^{\mathrm{a}}$ & $177.95^{\mathrm{a}}$ & 5.73 & $\star *$ & * & $\star *$ \\
\hline \multirow{3}{*}{$\begin{array}{l}\text { CREAT } \\
\mu \mathrm{mol} / \mathrm{L}\end{array}$} & 6 & $1.72^{\mathrm{d}}$ & $2.29^{c}$ & $4.96^{\mathrm{a}}$ & $3.96^{b}$ & 0.212 & $\star \star$ & * & $\star \star$ \\
\hline & 11 & $21.36^{\mathrm{b}}$ & $26.61^{a}$ & $25.80^{\mathrm{a}}$ & $20.76^{\mathrm{b}}$ & 0.59 & ns & ns & $\star *$ \\
\hline & 15 & $39.19^{a}$ & $28.12^{\mathrm{b}}$ & $21.96^{\mathrm{b}}$ & $24.12^{b}$ & 1.36 & $\star \star$ & * & * \\
\hline \multirow{3}{*}{$\begin{array}{l}\text { BIL } \\
\mu \mathrm{mol} / \mathrm{L}\end{array}$} & 6 & 8.7 & 9.78 & 8.53 & 7.82 & 0.164 & ** & ns & ** \\
\hline & 11 & 9.20 & 8.80 & 8.59 & 9.85 & 0.139 & ns & ns & $\star \star$ \\
\hline & 15 & 8.61 & 8.36 & 9.65 & 7.36 & 0.182 & ns & ** & $\star *$ \\
\hline \multirow{3}{*}{$\begin{array}{l}\text { UREA } \\
\mu \mathrm{mol} / \mathrm{L}\end{array}$} & 6 & 0.83 & 0.74 & 0.90 & 0.70 & 0.044 & ns & ns & ns \\
\hline & 11 & $1.06^{\mathrm{ab}}$ & $1.15^{\mathrm{a}}$ & $0.89^{b}$ & $0.92^{\mathrm{ab}}$ & 0.035 & ** & ns & ns \\
\hline & 15 & 1.07 & 1.07 & 0.93 & 0.92 & 0.032 & * & ns & ns \\
\hline
\end{tabular}

a,b,c means within the row with no common superscript differ significantly at $P \leq 0.05$ (compared with Group I)

ns: not significant $(P>0.05) ;{ }^{*}(P \leq 0.05) ;{ }^{* \star}(P \leq 0.01)$.

UA: uric acid; CREAT: creatinine; BIL: bilirubin. 
Table 6 Enzymatic (superoxide dismutase, catalase) and low-molecular antioxidant parameters of blood plasma of turkey hens

\begin{tabular}{|c|c|c|c|c|c|c|c|c|c|}
\hline \multirow{3}{*}{ Parameter } & \multirow{3}{*}{$\begin{array}{l}\text { Week of } \\
\text { age }\end{array}$} & \multicolumn{2}{|c|}{ Soybean oil } & \multicolumn{2}{|c|}{ Linseed oil } & \multirow{3}{*}{ SEM } & \multirow{2}{*}{\multicolumn{3}{|c|}{ Significance }} \\
\hline & & dl-alfa- & RRR-d-alfa- & dl-alfa- & RRR-d-alfa- & & & & \\
\hline & & $\begin{array}{c}\text { tocopherol } \\
\text { I-control }\end{array}$ & $\begin{array}{c}\text { tocopherol } \\
\text { II }\end{array}$ & $\begin{array}{c}\text { tocopherol } \\
\text { III }\end{array}$ & $\begin{array}{c}\text { tocopherol } \\
\text { IV }\end{array}$ & & Oil & $\begin{array}{l}\text { Tocop } \\
\text { herol }\end{array}$ & $\begin{array}{c}\text { Oil* } \\
\text { tocopherol }\end{array}$ \\
\hline \multirow{3}{*}{$\begin{array}{l}\text { SOD } \\
\mathrm{U} / \mathrm{mL}\end{array}$} & 6 & 27.68 & 27.22 & 27.88 & 27.19 & 0.069 & ns & ** & ns \\
\hline & 11 & $29.41^{a}$ & $26.53^{b}$ & $27.94^{a b}$ & $26.90^{b}$ & 0.240 & ns & ** & $\star \star$ \\
\hline & 15 & $28.13^{c}$ & $32.20^{\mathrm{b}}$ & $36.02^{\mathrm{a}}$ & $33.5^{\mathrm{b}}$ & 0.520 & $\star *$ & ns & ** \\
\hline \multirow{3}{*}{$\begin{array}{l}\text { CAT } \\
\text { U/mL }\end{array}$} & 6 & $4.98^{b}$ & $4.68^{b}$ & $6.87^{\mathrm{a}}$ & $5.71^{\mathrm{ab}}$ & 0.262 & ** & ns & ns \\
\hline & 11 & $5.72^{\mathrm{ab}}$ & $5.65^{\mathrm{ab}}$ & $7.96^{a}$ & $5.01^{b}$ & 0.39 & ns & * & ns \\
\hline & 15 & $4.79^{a}$ & $4.04^{a}$ & $3.91^{b}$ & $1.85^{b}$ & 0.270 & $\star \star$ & $\star *$ & ns \\
\hline \multirow{3}{*}{$\begin{array}{l}\text { FRAP } \\
\mu \mathrm{mol} / \mathrm{L}\end{array}$} & 6 & $36.22^{b}$ & $43.38^{a}$ & $44.03^{a}$ & $43.38^{a}$ & 1.52 & ns & ns & ns \\
\hline & 11 & $57.69^{b}$ & $64.41^{\mathrm{ab}}$ & $62.03^{\mathrm{ab}}$ & $68.54^{\mathrm{a}}$ & 1.50 & ns & * & ns \\
\hline & 15 & $55.74^{\mathrm{b}}$ & $62.01^{\mathrm{ab}}$ & $71.36^{a}$ & $67.88^{\mathrm{ab}}$ & 1.85 & $\star \star$ & ns & ns \\
\hline \multirow{3}{*}{$\begin{array}{l}\text { Vitamin C } \\
\mathrm{mg} / \mathrm{L}\end{array}$} & 6 & $0.223^{\mathrm{a}}$ & $0.179^{b}$ & $0.177^{\mathrm{b}}$ & $0.170^{b}$ & 0.006 & $\star \star$ & * & * \\
\hline & 11 & $0.230^{\mathrm{a}}$ & $0.20^{\mathrm{ab}}$ & $0.14^{b}$ & $0.20^{\mathrm{ab}}$ & 0.01 & * & ns & * \\
\hline & 15 & $0.174^{\mathrm{a}}$ & $0.158^{\mathrm{ab}}$ & $0.128^{b}$ & $0.153^{\mathrm{ab}}$ & 0.006 & * & ns & ns \\
\hline \multirow{3}{*}{$\begin{array}{l}\text { Vitamin } \mathrm{E} \\
\mu \mathrm{g} / \mathrm{mL}\end{array}$} & 6 & $0.43^{\mathrm{ab}}$ & $0.40^{\mathrm{b}}$ & $0.45^{a}$ & $0.46^{a}$ & 0.004 & ** & * & ** \\
\hline & 11 & $0.38^{\mathrm{ab}}$ & $0.36^{b}$ & $0.40^{a}$ & $0.40^{\mathrm{a}}$ & 0.003 & $* *$ & * & $\star \star$ \\
\hline & 15 & $0.29^{a b}$ & $0.28^{b}$ & $0.30^{\mathrm{ab}}$ & $0.31^{a}$ & 0.002 & $\star *$ & ns & $\star \star$ \\
\hline \multirow{3}{*}{$\begin{array}{l}\text { GSSG+GSH } \\
\mu \mathrm{mol} / \mathrm{L}\end{array}$} & 6 & $0.120^{b}$ & $0.134^{\mathrm{a}}$ & $0.135^{a}$ & $0.138^{\mathrm{a}}$ & 0.0009 & $\star \star$ & $\star \star$ & ns \\
\hline & 11 & $0.129^{b}$ & $0.132^{\mathrm{ab}}$ & $0.135^{a}$ & $0.136^{\mathrm{a}}$ & 0.0008 & $\star *$ & ns & ns \\
\hline & 15 & $0.130^{b}$ & $0.144^{\mathrm{a}}$ & $0.135^{\mathrm{b}}$ & $0.141^{\mathrm{a}}$ & 0.0010 & $\star \star$ & $* *$ & ns \\
\hline
\end{tabular}

$\overline{\mathrm{a}, \mathrm{b}, \mathrm{c}}$ means within the row with no common superscript differ significantly at $P \leq 0.05$ (compared to Group I).

ns: not significant $(P>0.05) ;{ }^{*}(P \leq 0.05) ;{ }^{* *}(P \leq 0.01)$.

SOD: superoxide dismutase; CAT: catalase; FRAP: ferric reducing ability of plasma; GSSG+GSH: glutathione. 
Table 7 Lipid peroxidation parameters (peroxides, malondialdehyde) and mineral elements (manganese, selenium) of blood plasma of turkey hens

\begin{tabular}{|c|c|c|c|c|c|c|c|c|c|}
\hline \multirow{3}{*}{ Parameter } & \multirow{3}{*}{$\begin{array}{l}\text { Week of } \\
\text { age }\end{array}$} & \multicolumn{2}{|c|}{ Soybean oil } & \multicolumn{2}{|c|}{ Linseed oil } & \multirow{3}{*}{ SEM } & \multirow{2}{*}{\multicolumn{3}{|c|}{ Significance }} \\
\hline & & dl-alfa- & RRR-d-alfa- & dl-alfa- & RRR-d-alfa- & & & & \\
\hline & & $\begin{array}{l}\text { tocopherol } \\
\text { I-control }\end{array}$ & $\begin{array}{c}\text { tocopherol } \\
\text { II }\end{array}$ & $\begin{array}{c}\text { tocopherol } \\
\text { III }\end{array}$ & $\begin{array}{c}\text { tocopherol } \\
\text { IV }\end{array}$ & & Oil & Tocopherol & $\begin{array}{c}\text { Oil* } \\
\text { tocopherol }\end{array}$ \\
\hline \multirow{3}{*}{$\begin{array}{l}\mathrm{H}_{2} \mathrm{O}_{2} \\
\mu \mathrm{mol} / \mathrm{L}\end{array}$} & 6 & $3.51^{a}$ & $1.71^{b}$ & $1.07^{\mathrm{b}}$ & $1.55^{b}$ & 0.176 & ** & ** & ** \\
\hline & 11 & $3.98^{\mathrm{a}}$ & $2.22^{b}$ & $1.10^{c}$ & $2.08^{b}$ & 0.190 & ** & * & $\star *$ \\
\hline & 15 & 2.05 & 1.64 & 1.82 & 1.83 & 0.09 & ns & ns & ns \\
\hline \multirow{3}{*}{$\begin{array}{l}\text { MDA } \\
\mu \mathrm{mol} / \mathrm{L}\end{array}$} & 6 & $0.85^{a}$ & $0.35^{b}$ & $0.36^{b}$ & $0.30^{b}$ & 0.042 & ** & ** & ** \\
\hline & 11 & $1.41^{\mathrm{a}}$ & $0.67^{c}$ & $0.50^{d}$ & $0.84^{b}$ & 0.058 & ** & $\star *$ & ** \\
\hline & 15 & $0.67^{b}$ & $0.96^{a}$ & $0.95^{\mathrm{a}}$ & $0.78^{\mathrm{ab}}$ & 0.03 & ns & ns & $\star *$ \\
\hline \multirow{3}{*}{$\begin{array}{l}\text { Manganese } \\
\mu \mathrm{mol} / \mathrm{L}\end{array}$} & 6 & 0.46 & 0.45 & 0.45 & 0.46 & 0.004 & ns & ns & ns \\
\hline & 11 & 0.53 & 0.54 & 0.52 & 0.53 & 0.006 & ns & ns & ns \\
\hline & 15 & 0.49 & 0.51 & 0.51 & 0.50 & 0.004 & ns & ns & ns \\
\hline \multirow{3}{*}{$\begin{array}{l}\text { Selenium } \\
\mu \mathrm{mol} / \mathrm{L}\end{array}$} & 6 & 84.3 & 82.8 & 83.4 & 86.5 & 1.25 & ns & ns & ns \\
\hline & 11 & $85.6^{b}$ & $90.1^{\mathrm{ab}}$ & $92.1^{\mathrm{ab}}$ & $102.8^{a}$ & 1.52 & $\star *$ & $\star *$ & $* *$ \\
\hline & 15 & 88.3 & 97.9 & 90.2 & 92.7 & 1.46 & ns & * & ns \\
\hline
\end{tabular}

a, b, c. means within the row with no common superscript differ significantly at $P \leq 0.05$ (compared with Group I).

ns: not significant $(P>0.05) ;{ }^{*}(P \leq 0.05)$; ${ }^{\star \star}(P \leq 0.01)$.

$\mathrm{H}_{2} \mathrm{O}_{2}$ : peroxides; MDA: malondialdehyde. 
the feed mixture with linseed oil with the addition of RRR-d-alpha-tocopherol, the reduced activity of CAT was observed as early as eleven weeks old. Nonetheless, changes in the activity of CAT were affected to a greater extent $(P \leq 0.01)$ by tocopherol in the diet (Table 6$)$ than by linseed oil. The administration of linseed oil with synthetic vitamin E (Group III) or natural vitamin E (Group IV) in a feed mixture contributed to an increase in FRAP in respect of the Group I. In Group III, which was fed linseed oil with the synthetic form of vitamin E, analyses showed a reduced level of vitamin C over the entire experimental period (Table 6). This increased level of FRAP and the diminished level of vitamin C were owing to the application of linseed oil. Groups fed the feed mixtures with linseed oil with different forms of tocopherol (Groups III and IV) were characterized by higher $(P \leq 0.05)$ concentrations of tocopherol. This effect resulted from the application of linseed oil, but not from different forms of tocopherol. In the hens receiving natural vitamin $E$, at the end of the rearing period (fifteenth week of life) analyses demonstrated a higher (by 9.6\%) level of glutathione than in Group 1. This increased level of glutathione was equally affected by linseed oil and RRR-d-alphatocopherol. In turn, the application of RRR-d-alpha-tocopherol resulted from an increased concentration of selenium in blood plasma of the turkey hens from Groups II and IV (Table 7). Although in particular weeks of life (weeks 6, 11 and 15) the concentrations of urea, uric acid and bilirubin in their blood plasma differed, when the entire period of observation was considered, no significant differences were observed among the groups in the values of those parameters (Table 5). Highly varying changes in these parameters were recorded when linseed oil was administered to feed mixtures. Furthermore, when compared with Group 1, a significant increase was recorded in the plasma level of creatinine in 6- and 11-week-old turkey hens from Groups II - IV. In contrast, in the fifteenth week of life, the level of creatinine in certain experimental groups was lower $(P \leq 0.05)$ than in the control birds, that is, by $28.2 \%$ in Group II, by $44 \%$ in Group III and by 38.4 in Group IV. This decrease undoubtedly affected the final (mean) lower $(P \leq 0.05)$ concentration of this parameter in blood plasma of the turkey hens from Group IV. Nevertheless, as indicated by data presented in Table 5, none of the experimental factors influenced these changes in creatinine level.

\section{Discussion}

Haematological, immunological and redox analyses of blood are of great significance in evaluating the health status of birds. Their values are determined by a number of factors, including age, sex, breed, feeding, physiological condition and rearing technology. Birds are also characterized by great individual differences in these parameters. Hence, lack of consistency is quite likely in changes of these blood markers in the growth process of the birds. This leucocytosis, that is, an increased white blood cell count, may indicate the pathological process in the bird's body. However, the increase noted in the total leucocytes count exclusively at the initial stage of the rearing period may be owing to the stimulation of the immune system of the birds by PUFAs and compounds (vitamins, polyphenols) present in linseed oil and soybean oil (Hylands \& Poulev, 1998; Ognik et al., 2012). As well as the PUFAs, oil and linseed oil in particular, is a rich source of substances with antioxidative properties, for example vitamin $E$, that may stimulate the immunity of the birds (Ramadan \& Moersal, 2006; Kouba \& Mourot, 2011), because vitamins can stimulate the migration of monocytes and phagocytosis (Rocha, 1989). The stimulation of the immune system of birds because of this leucocytosis was demonstrated in experiments with turkey hens receiving immunostimulants, Bioaron $\mathrm{C}$ and Biostymina (Sembratowicz et al., 2004a). As reported by Koncicki \& Krasnodębska-Depta (2005), in birds, the percentage of lymphocytes (lymphocytosis) may increase physiologically, whereas lymphopenia (reduced number of lymphocytes) is often observed when birds are exposed to stress and monocytopenia in various pathological states. In contrast, negligible changes were observed sporadically in the numbers of basocytes and eosinocytes. Therefore, their percentage contribution in a leucogram is of no diagnostic significance. The values of morphological blood markers (WBC and leucocytic system) achieved in the experiment in Group I and Groups II - IV corresponded with results reported for turkeys by other researchers (Sembratowicz et al., 2004a; b; Koncicki \& Krasnodębska-Depta, 2005; Ognik \& Sembratowicz, 2009). The birds that were examined did not manifest pathological symptoms and were in good health. The likely effect of the polyunsaturated fatty acids in linseed oil may be indicated by the stimulation of the immune system, expressed by the increase in percentage of PC and NBT-reducing cells, particularly in Group III. The composition of dietary fatty acids is reflected in the fatty acid composition of the cell membrane of lymphocytes and other cells of the immunological system (Swiątkiewicz \& Koreleski, 2007). The acids that directly affect such immune processes as proliferation of lymphocytes, production of cytokines and activity of NK cells include oleic, linoleic, conjugated linoleic (CLA), linolenic, arachidic, eicosapentaenoic (EPA) and docosahexaenoic acids (DHA). The most beneficial effect is ascribed to long-chain polyunsaturated fatty acids of the n-3 family (LC PUFA n-3), EPA and DHA in particular, which display anti-inflammatory activity, thus suppressing the production of pro-inflammatory eicosanoids, including IL-1 and IL-6 (Świątkiewicz \& Korolewski, 2007). Rich sources of those acids include flax seed and linseed oil. The opposite properties, that is, pro-inflammatory, are displayed by n-6 PUFAs, which predominate in soybean oil. However, the 
results in the study did not indicate inflammatory states in the groups administered this oil. The stimulation of the humoral response of chickens to an increased supply of $n-6$ PUFA because of feed mixture supplementation with various oils has been confirmed in a study by $\mathrm{He}$ et al. (2007). In addition, several investigations (Rey et al., 2004; Nuernberg et al., 2005; Hassan et al., 2011) have demonstrated a significant effect on the immunity of poultry when applying various fat sources.

A significant element in assessing the efficacy of feed additives in animal feeding may be the course of metabolic processes, which is expressed in, among other things, changes in prooxidative and antioxidative blood indices. A measure of the antioxidative status of the body is the balance or ratio between oxidative factors, namely lipid peroxidation products (peroxide radicals, malondialdehyde), and the endogenous and exogenous substances that suppress radicals, including enzymes such as SOD, glutathione peroxidase and CAT, as well as many low-molecular antioxidants such as bilirubin, creatinine, uric acid, urea, glutathione, active forms of vitamins $(\mathrm{E}$ and $\mathrm{C})$ and dissociated cations/anions of metals $(\mathrm{Cu}$, $\mathrm{Zn}, \mathrm{Mn}, \mathrm{Fe}, \mathrm{Se})$, constituting the FRAP (Bartosz, 2004). The lower $(P \leq 0.05)$ activity of SOD that was observed in the initial period of rearing (eleventh week of life) in blood plasma of the turkey hens fed a feed mixture with soybean oil (Group II) and linseed oil (Group IV) with the addition of RRR-d-alpha-tocopherolm, compared with Group I, points to the protective effect of the highly active natural vitamin $\mathrm{E}$ against the peroxidation processes of fatty acids occurring in the oils. The protective properties of natural tocopherol are of special significance in applying linseed oil that is rich in PUFAs that contain three unsaturated double bonds, for example $\alpha$-LNA. These acids are particularly susceptible to rapid oxidation to hydroperoxides and other products of lipid peroxidation, which may stimulate oxidative stress (Choe \& Min, 2006). The addition of vitamin E stimulates the antioxidative mechanisms (Ognik \& Wertelecki, 2012). Thus, the diminished activity of SOD may be owing to the engagement of the enzyme in the antioxidative processes, particularly in the reaction of dismutation aimed at eliminating peroxides from the environment, thus preventing the chain reactions of peroxidation and the formation of other reactive forms of oxygen. In contrast, the significant increase in the activity of SOD recorded in Groups II - IV at the end of the rearing period (fifteenth week of life), compared with Group I, may be because of the stimulation of the antioxidative system as a result of the joint administration of dl-alpha-tocopherol and RRR-d-alpha-tocopherol particularly with linseed oil, which is a source of low-molecular antioxidants. In addition, the application of linseed oil together with RRR-d-alphatocopherol suppressed the activity of CAT, particularly in the final stage of rearing. However, this effect was attributed more to the highly antioxidative properties of the natural form of tocopherol. The enhanced activity of CAT is usually observed as a result of the generation of high quantities of hydrogen peroxide in the body (Bartosz, 2004). The decreased levels of lipid peroxidation products and the increased plasma levels of FRAP, uric acid, glutathione, vitamin E and selenium determined in Groups II, III and IV may indicate the highly antioxidative properties of RRR-d-alpha-tocopherol and linseed oil. Interestingly, however, although the experimental factors (linseed oil and RRR-d-alpha-tocopherol) equally affected the reduction in lipid peroxidation products, they were observed to activate the non-enzymatic mechanism of the antioxidative defence slightly differently. The linseed oil influenced mainly an increase in FRAP, UA and vitamin E, and RRR-d-alpha-tocopherol mainly an increase in the levels of glutathione, vitamin E and selenium. The antioxidative properties of linseed oil have been confirmed in research by Ramadan \& Moersel (2006). The FRAP is constituted by uric acid (60\%), ascorbic acid (15\%), glutathione (10\%) and tocopherols (5\%) (Bartosz, 2004). The increased level of FRAP in birds administered linseed oil may result from the statistically significant increase in the level of uric acid, which is the major FRAP component.

The increased FRAP level in blood plasma is usually a desirable phenomenon, because it provides better protection of cells and tissues against the toxic effect of reactive oxygen species. In turn, glutathione is the most abundant thiol (includes the group S-H) which occurs in cells in high concentrations, reaching 1 - 10 $\mathrm{mmol} / \mathrm{L}$. Its principal function is to maintain the thiol groups of protein in a reduced state, which in many cases is indispensable to the functional activity of proteins, including antioxidation (Bartosz, 2004). The presence of compounds with a high antioxidative activity in food may affect the suppression of lipid peroxidation products, and enhance the activity of enzymatic and non-enzymatic antioxidants, for example selenium, in the blood and tissues of animals.

\section{Conclusions}

The results of the experiment indicate that the administration of linseed oil in feed mixtures for turkey hens evoked an insignificant stimulating effect on the immune system (increased count of NBT-reducing cells) and antioxidative system (increased levels of FRAP, UA, vitamin E). The study showed that the addition of the natural form of RRR-d-alpha-tocopherol with soybean and linseed oils stimulated the mechanisms of the antioxidative defence system (reduction in $\mathrm{H}_{2} \mathrm{O}_{2}$, MDA, CAT, increase in GSSG+ GSH, selenium) more effectively than dl-alpha-tocopherol acetate addition with these oils. 
It may be possible to use the natural form of tocopherol in diets rich in linoleic and linolenic acid (soybean/linseed oil) without detrimental effect on to reox and immune status of turkey hens. It should be emphasized, however, that, despite the higher dosage, the commonly used tocopherol acetate is cheaper. Thus, from an economic point of view, the use of linseed oil with the synthetic form of vitamin $E$ is worth recommending.

\section{Acknowledgments}

The paper was supported by project No. N N311 633738 from Ministry of Science and Higher Education, Poland.

\section{References}

Asheber, A., 2012. Introduction to Design and Analysis of Experiments with the SAS System (Stat 7010 Lecture Notes). Discrete and Statistical Sciences. Auburn University.

Bartosz, G., 2004. Second face of oxygen. PWN Warszawa.

Bomski, J., 1989. Basic Laboratory Hematological Analyses. PZWL Warszawa.

Calder, P.C., Yaqoob, P., Thies, F., Wallace, F.A. \& Miles, E.A., 2002. Fatty acids and lymphocyte functions. Br. J. Nutr. 87, 31-48.

Choe, E. \& Min, D.B., 2006. Mechanisms and factors for edible oil oxidation. Compre. Rev. Food Sci. Food Safet. 5, 169-186.

Czech, A., Ognik, K. \& Laszewska, M., 2012. Influence of linseed oil on content of the fatty acids in feed mixtures and muscles of turkey hens and blood profile lipids. Ann. EE. 30 (4), 9-17.

Gay, C. \& Gębicki, J.M., 2000. A critical evaluation of the effect of sorbitol on the ferric-xylenol orange hydroperoxide assay. Anal. Biochem. 284, 217-220.

Hassan, M.S.H., Nadia, L., Radwan, A.M., Khalek, A. \& Abd El-Samad, M.H., 2011. Effect of different dietary linoleic acid to linolenic acid ratios on some productive, immunological and physiological traits of Dandarawy chicks. Egypt. Poult. Sci. J. 31, 1-5.

He, X.Y. \& Guo, Y., 2007. Effects of different dietary oil sources on immune function in cyclophosphamide immunosuppressed chickens. Anim. Feed Sci. Techn. 139, 186-200.

Hylands, P.J. \& Poulev. A., 1998. Immunostimulants: maximizing the health and efficiency of animals through plant - derived biomolecules. Passport to the Year 2000. Biotechnology in the feed industry. In: Proceedings of Alltech's 14th Annual Symposium Herbs and Spices: Implication for Modern Animal Production. Nottingham University Press, Nottingham U.K. 117-131.

Kania, M., Michalak, M., Gogolewski, M. \& Hoffmann, A., 2004. Antioxidative potential of substances contained in cold pressed soybean oil and after each phase of refining process. Acta Sci. Pol., Technol. Aliment. 3 (1), 113-121.

Kaufmann, H.P., 1958. Analyse de Fette und Fettproducte, 1, 980, Springer-Verla, Berlin, Germany.

Koncicki, A. \& Krasnodębska-Depta, A., 2005. Opportunities to apply the hematological and biochemical test results in poultry disease diagnostics. Vet. Mag. 5, 20-24.

Kouba, M. \& Mourot, J., 2011. A review of nutritional effects on fat composition of animal products with special emphasis on $\mathrm{n}-3$ polyunsaturated fatty acids. Biochem. 93, 13-17.

Manz, U.Y. \& Philipp, K., 1981. A method for the routine determination of tocopherols in animal feed and human foodstuffs with the aid of high performance liquid chromatography. Int. J. Vit. Nutr. Res. 51, 342-348.

NRC, 1994. Nutrient Requirements of Poultry. Ninth Revised Edition. National Research Council, National Academy Press, Washington, D.C., USA.

Nuernberg, K., Fischer, K., Nuernberg, G., Kuechnmeister, U., Klosowska, D., Eliminowska-Wenda, G., Fiedler, I. \& Ender, K., 2005. Effects of dietary olive and linseed oil on lipid composition, meat quality, sensory characteristics and muscle structure in pigs. Meat Sci. 70, 63-74.

Ognik, K. \& Sembratowicz, I., 2009. Influence of different rates of new synthetised 5-oxo-1.2.4-triazyne derivative on some immunological and hematological indices of blood of turkey hens. J. Appl. Anim. Res. 36, 235-237.

Ognik, K. \& Wertelecki, T., 2012. Effect of different vitamin E sources and levels on selected oxidative status indices in blood and tissues as well as on rearing performance of slaughter turkey hens. J. Appl. Poult. Res. 21 (2), 259-271.

Ognik, K., Czech, A., Sembratowicz, I. \& Laszewska, M., 2012. Influence of linseed oil on selected parameters of blood and production performance of turkey hens. Ann. EE. 30 (4), 76-83.

Park, B.H., Fikrig, S.M. \& Smithuick, E.M., 1968. Infection and nitroblue tetrazolium reduction by neutrophils. Lancet 2, 532. 
Pinkiewicz, E., 1971. Laboratory Diagnostics of Animal Diseases. Higher School Agriculture Lublin, Poland, 481-482.

Prescha, A., Siger, A., Lorenc-Kukuła, K., Biernat, J., Nogala-Kałucka, M. \& Szopa, J., 2008. Study of composition and susceptibility to oxidation of oil form geneticaly modified flaxseed. Bromat. Chem. Toksykol. 60 (3), 286-292.

Ramadan, M.F. \& Moersel, J.T., 2006. Screening of the antiradical action of vegetable oils. J. Food Comp. Anal. 19, 838-842.

Rey, A.I., Lopez-Bote, C.J., Kerry, J.P., Lynch, P.B., Buckley, D.J. \& Morrissey, P.A., 2004. Modification of lipid composition and oxidation in porcine muscle and muscle microsomes as affected by dietary supplementation of n-3 with either n-9 or n-6 fatty acids and a-tocopheryl acetate. Anim. Feed Sci. Techn. 113, 223-238.

Rocha, N.P., 1989. Vitamin E stimulates endotoxin-inhibited monocyte migration and phagocytosis in vivo. Braz. J. Med. Biol. Res. 22, 1401-1403.

Salih, M., Smith, D.M., Price, J.F. \& Dawson, L.E., 1987. Modified extraction 2-thiobarbituric acid method for measuring lipid oxidation in poultry. Poult. Sci. 66, 1483-1488.

Second Local Ethical Committee for Animal Experiments in Lublin, 2009. Resolution Number 11/2009 of 20 January 2009. University of Life Sciences. Akademicka 13, Lublin. Poland.

Sembratowicz, I., Ognik, K. \& Truchliński, J., 2004a. Influence of Biostymina i Bioaron C as natural biostimulators on some immunological indices of blood and performance of turkey hens. Ann. EE. 42, 318-323.

Sembratowicz, I., Ognik, K., Truchliński, J. \& Modzelewska-Banachiewicz, B., 2004b. The influence of 1.2.4-triazole and 5-oxo-triazyne derivatives on some blood and performance indices of turkey hens. J. Anim. Feed Sci. 13, 39-42.

Siwicki, A.K. \& Anderson, D.P., 1993. Immunostimulation in fish: Measuring the effects of stimulants by serological and immunological methods. U.S. Fish and Wildlife Service Inland Fisheries Institute in Olsztyn, 321-326.

Świątkiewicz, S. \& Koreleski, J., 2007. Feed additives enhancing immune responses in poultry. Medicin Vet. 63 (11), 1291-1295. 